\title{
Can standardisation of the unit costs of wood extraction be applied in the financial system of the State Forests?
}

\author{
Janusz Kocel, Krzysztof Jodłowski 凶
}

Forest Research Institute, Department of Forest Resources Management, Sękocin Stary, Braci Leśnej 3, 05-090 Raszyn, Poland, e-mail: k.jodlowski@ibles.waw.pl

\begin{abstract}
The paper presents a method for grouping forest districts that are characterised by similar natural and forest conditions and the results of standardisation of wood extraction costs for forest districts and regional directorates of the State Forests. The adopted standard costs referred to the costs which determine the reasonable level of costs necessary to perform a specific management task in the given natural, forest and economic conditions of forest districts. Forest districts were grouped based on the forest habitat types and the land diversity index $\left(\mathrm{W}_{\text {tri }}\right)$, which were determined with statistical methods to be the factors that shape wood extraction costs. In order to determine the standard unit costs of wood extraction, source materials for the year 2017 have been used, which had been obtained from the State Forests Information System for all forest districts in the country. The method of standardising wood extraction unit costs on the basis of forest district groups with similar natural and forest conditions was reduced in 2017 to the designation of eight uniform forest district groups in terms of forest habitat type structure and $\mathrm{W}_{\text {tri }}$ index. Standard unit costs of wood extraction, determined on the basis of the methodology presented in the paper, should be used in the State Forests' financial system.
\end{abstract}

\section{KEY WORDS}

wood extraction, standard costs, forest districts grouping method, the State Forests' financial system

\section{INTRODUCTION}

From the economic point of view, costs are the most important measure featuring the efficiency of every business organisation, as they largely reflect activities at most management levels. For this reason, it is necessary to systematically analyse costs and identify the factors that cause changes in their level and structure (Jerzemowska 2018; Gabrusewicz 2019; Nowak 2018). To make reasonable business decisions, model (standard) costs are necessary, which reflect the values obtained by average units in a given business organisation and are characterised by certain features. Standard costs constitute a benchmark for comparing incurred (real) costs and analysing possible deviations from the pattern (Gabrusewicz et al. 2014), as well as they constitute the basis for determining ex ante costs for the planned volume of tasks at a business organisation. Thus, they are the costs of consuming property resources (production factors), substantiated by technological conditions and standards (Sojak 2017). Studies on the standardisation of forestry works' costs were, for the first time, 
undertaken in Poland at the end of the 1990s (Kocel et al. 1999). The main reason for this was the absence of a single cost setting system in the forest practice so far. All analyses related to the amounts of planned and implemented costs were carried out exclusively at the level of the State Forests' regional directorates. Thus, the management of the State Forests' regional directorates was left free to shape the cost level between their subordinate forest districts. The costs were awarded 'on a discretionary' basis. Their amounts were often forced by forest district managers who argued that high expenses were due to unique features of their forest districts. The aforementioned activities led to a total distortion of the relation between the volume of costs and their determining factors. The standard costs developed at that time (also referred to as model costs) for the years 1998-2000 were used to verify the financial result of the State Forests' regional directorates and forest districts (Regulation 1998; Kocel and Grabowski 2002).

A certain type of standardisation, or rather the estimation of costs related to wood harvesting in German conditions, is based on experience and results in provisions which have been included in official guidelines. The guidelines are published annually, for example, by the Department of Forestry or Environment in German Länder such as North Rhine-Westphalia or Brandenburg. Wood harvesting costs specified therein depend exclusively on the estimated total volume of harvested wood, as well as trees' age and species. They do not take into account detailed harvesting parameters such as the type of machinery or the quantity and location of strip roads in a given stand (Losch et al. 2015).

Harvesting and extraction of wood are among the most cost-intensive operations in forestry. At the same time, this group of costs may be slightly limited in individual forest districts, as it is inextricably linked to the possibility of gaining revenues from the sale of raw wood in the system applied by the State Forests, where the harvested assortments are sold mainly at extraction roads. For this reason, identifying the components of economic calculation constitutes an extremely important element of efficient forest management. In addition, the process of greening forest management forces an increase in the share of deciduous species, which contributes to an increase in the share of multi-species stands, as well as an increase in the share of stands in older age classes. The process requires not only higher qualifica- tions of the management and executive personnel, but also greater workload and increased costs (Zając and Kaliszewski 2014).

It is also crucial to identify the factors that shape the cost consumption of cutting and obtaining raw wood material (Szewczyk et al. 2013). The ability to recognise working conditions and their impact on the efficiency of logging is important both for the State Forests and the forest companies working for their benefit, since both parties are obliged to conduct their businesses on the basis of economic calculation. The variability of external conditions in the logging process is manifested in the diversity of work efficiency in various stands and in different field conditions. Even for comparable stand conditions and similar technical equipment, significant differences are observed (Laurow 1999; Sadowski et al. 2014). Diversified work efficiency, and thus its timeconsuming nature, is therefore a typical feature of the logging process at all its stages. The appropriate estimation of time consumption levels is a decisive matter for forest contractors, as it allows for efficient shaping of service prices and submission of proposals in tender procedures. On the other hand, it enables, most of all, the State Forests to get the prices proposed by forestry companies right and eliminate low-priced offers that do not warrant the timely and appropriate service performance (Szewczyk et al. 2013). Determining the average labour consumption in given conditions is difficult and complex; therefore, it is even more needed to indicate the most reasoned factors that shape the costs of wood extraction, resulting from the least dispersible natural and forest conditions of the forest districts where it is carried out. Therefore, it is necessary to determine the factors that would enable grouping, with the use of statistical methods, forest districts of a similar impact on the level of incurred wood extraction costs. As a result, standard costs developed would allow for an appropriate construction of tender procedures and effective planning of commissioned works, and therefore for impartial economic calculations, which are important both from the point of contractors and forest districts (ordering parties).

All these mean that in order to have an efficiently operating financial system at the State Forests, it is necessary to deploy proven methods for setting standard unit costs of forestry works, which would allow, at the provisional stage of the plan, estimating costs result- 
ing from natural and forest conditions, as well as the economic environment of forest districts. Standardised costs of most basic activities of forest districts may also be used for current cost management in forest districts' operations. Their importance would come down to examining the correct shaping of real unit costs of works incurred by forest districts after the end of the financial year, by comparing them with the standard unit costs of individual works and by analysing deviations (Kocel et al. 2017).

The purpose of this article is to present the results of standardisation of unit costs of wood extraction using the method of grouping forest districts with similar natural and forest conditions and to compare them with incurred (real) costs, as well as to evaluate the standardisation method in terms of its application in the State Forests' financial system. In the course of conducted works, the basic study hypothesis was verified, according to which the forest habitat type (in terms of fertility and moisture content) and the land diversity index are the factors that shape wood extraction costs. Confirmation of the above hypothesis enabled the development of a method for determining standard unit costs of wood extraction.

\section{Material AND Methods}

The scope of this work includes the following: determining, on the basis of statistical analyses, factors that shape wood extraction costs, developing a method for standardising costs for this group of works, as well as assessing suitability of the developed method for use in the State Forests' financial system.

The source of data on the planned and real unit costs of wood extraction and the natural and forest factors that shape the costs of this forest work included databases of the State Forests Information System (SILP) from all forest districts in the country. Analytical materials for determining the factors that influence unit costs of wood extraction were from the year 2005 to 2012, and the materials necessary to develop standard unit costs of wood extraction and for their comparison with the real and planned unit costs of this operation were from the year 2017. Data on the land diversity index $\left(\mathrm{W}_{\text {tri }}\right)$ for all forest districts in the country were obtained from the Forest Management and Geodesy Bureau (BULiGL).
Information on the average monthly gross salary for the years 2005-2012 was obtained from the Local Data Bank of the Main Statistical Office.

In order to achieve the purpose and scope of the work, a methodological assumption was adopted consisting in dividing work into two stages. In the first stage, possible factors that influence the costs of wood extraction were identified. The second stage consisted in presenting the developed method of standardising this group of costs and assessing suitability of the developed method for use in the State Forests' financial system. Identification and understanding how cost-shaping factors operate is one of the most important stages in cost analysis (Gabrusewicz et al. 2014; Nowak 2018a, 2019). In order to identify the shaping factors, cause and effect relationships were searched for between the amount of costs incurred by forest districts and the natural and forest conditions, as well as the economic environment of the unit. When searching for these relationships, an analysis of correlation between the level of costs and specific parameters describing forest districts' management conditions was applied (Kocel et al. 2013, 2017). The paper presents correlation dependencies both according to the value of the Pearson linear correlation coefficient $r$ and descriptive statistics, where a very high impact was considered to be the correlation coefficient $r$ within the range of $0.8-0.9$, significant (average) impact to be $r$ within $0.4-0.6$, low (moderate) impact to be $r$ within $0.2-0.4$ and weak (low) impact to be $r$ within below 0.2 .

In the first stage, on the basis of the subject literature, consulting carried out in selected forest districts and regional directorates of the State Forests (RDSFs) and the authors' own experiences, a preliminary list was developed including factors that may affect shaping costs of wood extraction. Out of potential factors shaping the costs of this group of forestry works, the following were selected for statistical analyses: a) forest habitat type, b) land diversity index $\left.\left(W_{t r i}\right), \mathrm{c}\right)$ average size of forest compartment and d) average monthly gross remuneration. From the preliminary list of cost-shaping factors, forest habitat types and the average monthly gross remuneration were used to standardise the costs of selected silviculture works (Kocel et al. 2019; Kocel and Wysocka-Fijorek 2020), while the structure of obtained wood assortments and the surface share of species groups in the total area of forest districts were used 
in determining standard unit costs of cutting and assortment production.

Among the factors that influence unit costs of wood extraction, analysing the impact of a forest habitat type on extraction costs was based on the assumption that a specific habitat is characterised by difficulties with wood extraction due to its moisture content, a degree of turf cover, the occurrence of seedlings, underwood and undergrowth, as well as the terrain (upland and mountain habitats). On the other hand, inclusion of the land diversity index $\left(\mathrm{W}_{\mathrm{tri}}\right)$ in the factors shaping the costs of logging was connected with the fact that in lowland conditions, there are also areas of varied relief, causing significant difficulties in the performance of wood extraction. The land diversity index $\left(\mathrm{W}_{\text {tri }}\right)$ is an indicator used in planning and cost accounting for forest management works. To calculate the value of the land diversity index $\left(\mathrm{W}_{\text {tri }}\right)$, the topographic ruggedness index is applied. This indicator is used to measure the heterogeneity and diversity (inhomogeneity) of the terrain according to the methodology developed by Riley et al. (1999):

$$
W_{t r i}=1+1 \times\left(\frac{N_{t r i}-T_{2}}{T_{1}-T_{2}}\right)
$$

where:

$W_{t r i}$ - land diversity index (the maximum difficulty 1.0 ),

$T_{1}-5$,

$T_{2}-59$,

$N_{t r i}$ - topographic ruggedness index for a given forest district.

The methodological basis for the development of standard unit costs of wood extraction for groups of forest districts with similar natural and forest conditions was the assumption, 'in similar natural and forest conditions of forest districts, costs of forestry works should be incurred at a similar level' (Kocel et al. 2013, 2019). In order to group forest districts, the method of cluster analysis with distance sorting (from a cluster centre) was applied in line with the analysis of observations with a constant interval. The 10 iteration option was used, which ensured determining the parameters appropriate for each forest district group. The cluster analysis method provided the 'most significant possible solution' as no a priori hypothesis was formulated at this stage of the study. From among the cluster analysis algorithms, the k-means clustering algorithm was selected.
For the so-designated groups of forest districts with a similar structure of forest habitat types and values of $\mathrm{W}_{\text {tri }}$ index, standard unit costs were calculated by determining an arithmetic mean for real costs of wood extraction, assuming the null hypothesis about the normality of feature distribution. To test the compliance of features' distribution with the normal distribution, the $\chi^{2}$ compliance test was applied. In the case of noncompliance of the distribution of an investigated feature with the normal distribution, a logarithmic transform was applied to bring the data to a normal distribution. After determining an arithmetic mean for each group, the observation range was determined from the mean in the 'minus' and 'plus' 2 standard deviations $(x \pm 2 \mathrm{~s})$, that is, $95 \%$ of observations in the group. Excluding 5\% of all observed variables from the calculations was a result of the assumption that this area should include 'outlier' observations, that is, costs incurred in conditions of natural disasters and unjustified costs (e.g. resulting from the rates paid to private companies below their own costs). For values within the range of $x \pm 2 \mathrm{~s}$, an arithmetic mean was calculated, which was considered as the standard costs of wood extraction (Kocel et al. 2013, 2019; Kocel 2018).

Due to the close to normal distribution of unit costs, descriptive statistics were determined for the planned, real and standard unit costs of wood extraction, specified based on 2017 data. In order to check the similarity of weighted averages (the size of tasks constituted a weight) of the planned, real and standard unit costs, a one-way analysis of variance in a completely randomised design was used. Pearson's linear correlation coefficients were set, and their significance was checked with the $t$-test to determine the relationship between the planned, real and standard unit costs of wood extraction developed according to the above method (Walesiak and Gatnar 2009; Zeliaś 2010).

\section{Results}

The highest values of $\mathrm{W}_{\text {tri }}$ index were recorded for the following forest districts out of all 430 forest districts in the country: Krościenko $\left(W_{t r i}=1.5924\right)$ from the area of the RDSF in Kraków, Węgierska Górka $\left(W_{t r i}=1.5922\right)$ from the area of RDSF in Katowice and Piwniczna Forest District $\left(W_{t r i}=1.5901\right)$ from the area of RDSF in 
Kraków. On the other hand, the lowest values of $W_{\text {tri }}$ index were obtained for the following forest districts: Świętoszów $\left(W_{t r i}=1.0541\right)$ from the area of RDSF in Wrocław, Drewnica $\left(W_{t r i}=1.063\right)$ from the area of RDSF in Warsaw and Żagań $\left(W_{t r i}=1.0644\right)$ from the area of RDSF in Zielona Góra.

In the process of developing a standardisation method for wood extraction unit costs, the existence of dependencies was examined both at the level of the State Forests in general and the individual RDSFs. The study of relationships between average real unit costs of wood extraction and the factors that shape the costs of forest works allowed to assess the strength of impact of regional conditions on the analysed factors. At the level of the State Forests, no correlation was found between the average real costs of wood extraction incurred by forest districts in 2005-2011, and the forest habitat types and the land diversity index $\left(W_{t r i}\right)$. On the other hand, such relationships were found at the level of the State Forests on the basis of data from the year 2012, where along with the increase in the share of fresh mixed coniferous forest (BMśw) and fresh coniferous forest (Bśw), the real costs of wood extraction decreased. The respective Pearson's correlation indices were $r=-0.28$ and -0.26 . In turn, the real costs of wood extraction increased along with the growth in the share of mountain forest (LG) and upland forest (Lwyż). The respective Pearson's correlation indices were $r=0.52$ and 0.35 .

The study of correlations carried out in the years 2005-2010 allowed, however, to confirm the relationship between the average real costs of wood extraction, and the forest habitat types and the land diversity index $\left(W_{t r i}\right)$ in certain RDSFs. And so, it could be noticed that along with the increase in the share of fresh coniferous forest (Bśw) and dry coniferous forest (Bs), that is, dry and easy accessible habitats, the real costs of wood extraction decreased. A moderate correlation ( $r$ index ranging from -0.31 to -0.39 ) was found in the RDSFs: in Piła, Poznań and Warsaw. In turn, the real costs of this forest work increased along with the increase in the share of wet forest (Lw) in the structure of forest habitat types. A moderate and significant correlation was recorded in forest districts under the RDSFs in Gdańsk $(r=0.61)$, Radom $(r=0.51)$ and Olsztyn $(r=0.33)$. A similar relationship was also noted with regard to the share of ash alder forest (OlJ) in the forest districts under the RDSFs in Poznań $(r=0.48)$, Gdańsk $(r=0.45)$ and
Olsztyn $(r=0.44)$. The impact of mountain habitats on the level of wood extraction costs was recorded in the RDSFs in Kraków, Krosno, Katowice and Wrocław. In the RDSFs in Krosno and Katowice, the costs of wood extraction increased along with an increase in the share of mountain mixed coniferous forest (BMG). Pearson's correlation indices were $r=0.90$ and 0.42 , respectively. In the RDSF in Krosno, the influence of upland ash alder forest (OlJwyż) in the structure of forest habitat types $(r=0.98)$ on the level of wood extraction costs was recorded. On the other hand, the increase in the real cost of wood extraction in the RDSF in Wrocław was influenced by the share of upland riparian forest (Lłwyż) and mountain coniferous forest (BG). Pearson's correlation indices reached $r=0.5$ and 0.35 , respectively.

A correlation between $W_{t r i}$ index and real costs of wood extraction was recorded in the years 2005-2010, mainly in the RDSF in Kraków $(r=0.50)$, Wrocław $(r=0.36)$, Katowice $(r=0.34)$ and Gdańsk $(r=0.29)$. This means that in the forest districts of the abovementioned RDSFs, the real costs of wood extraction increased along with an increase in the degree of terrain differentiation. In turn, in 2011, at the general level of the State Forests, a relationship was found between the planned and real costs of wood extraction and $W_{t r i}$ index. Pearson's correlation indices were $r=0.79$ and 0.19 , respectively. On the other hand, a significant relationship $(r=0.72)$ was found in 2012 at the level of the State Forests between the real costs of wood extraction and $\mathrm{W}_{\text {tri }}$ index. In 2012, a moderate relationship was also found between the real costs of wood extraction and the average size of forest compartment, where the Pearson correlation index was $r=-0.57$. This means that the real costs of wood extraction decreased as the average size of forest compartment increased.

Investigating the correlations between the average real costs of wood extraction incurred by the forest districts in 2005-2010 and the average monthly gross remuneration for the years 2005-2010 calculated for the State Forests in total and for the individual RDSFs showed no relationships between these variables at the level of the State Forests in total. However, examining this relationship showed a low level $(r=-0.39)$ exclusively for the RDSF in Zielona Gorra. This means that along with an increase in the average gross monthly remuneration in the forest districts under this directorate, the costs of wood extraction increased moderately. 
The above analyses led to the conclusion that the factors that shape the unit costs of wood extraction include forest habitat types and $\mathrm{W}_{\text {tri }}$ land diversity index.

Forest habitat types (fertility, humidity) and the land diversity index, determined through statistical analyses to be the main factors that shape the wood extraction costs, became the basis for designating groups of forest districts with similar natural and forest conditions. In terms of the structure of forest habitat types, forest districts were divided into three categories: I - mountain forest districts, with over 50\% share of mountain habitats; II - upland forest districts, with over $50 \%$ share of upland habitats and III - lowland forest districts, with over $50 \%$ share of lowland habitats.

Within the abovementioned categories, based on data from 2017, 12 groups of forest districts were designated with a similar structure of forest habitat types. In the category of mountain forest districts, three groups of forest districts were established (poor mountain, fertile mountain with the addition of upland and very fertile mountain forest districts) comprising 37 forest districts; in the category of upland forest districts, two groups were established (poor upland and fertile upland forest districts), which were created from 27 forest districts; and in the category of lowland forest districts, seven groups were created (two types of lowland poor, two types of lowland moderately fertile, two types of lowland fertile and one type of lowland humid) comprising 366 forest districts. The forest district groups that were classified based on the forest habitat types in 2017 were presented by Kocel et al. (2019).

Further, in terms of a similar value of the land diversity index, the forest districts were divided into eight groups. Based on statistical methods, eight groups of 'habitat and slope' forest districts were designated, which served to determine standard unit costs of wood extraction. The forest district groups that were classified based on the forest habitat types in 2017 and the $\mathrm{W}_{\text {tri }}$ index have been presented in Figure 1.

The most numerous habitat and slope group (group 4) comprised 118 forest districts, where the $W_{\text {tri }}$ index ranged from 1.068 to 1.846 . Forest districts in this group are characterised by the following type of habitats: lowland, moderately fertile 2 (64 forest districts), lowland fertile 1 (50 forest districts), lowland moder-
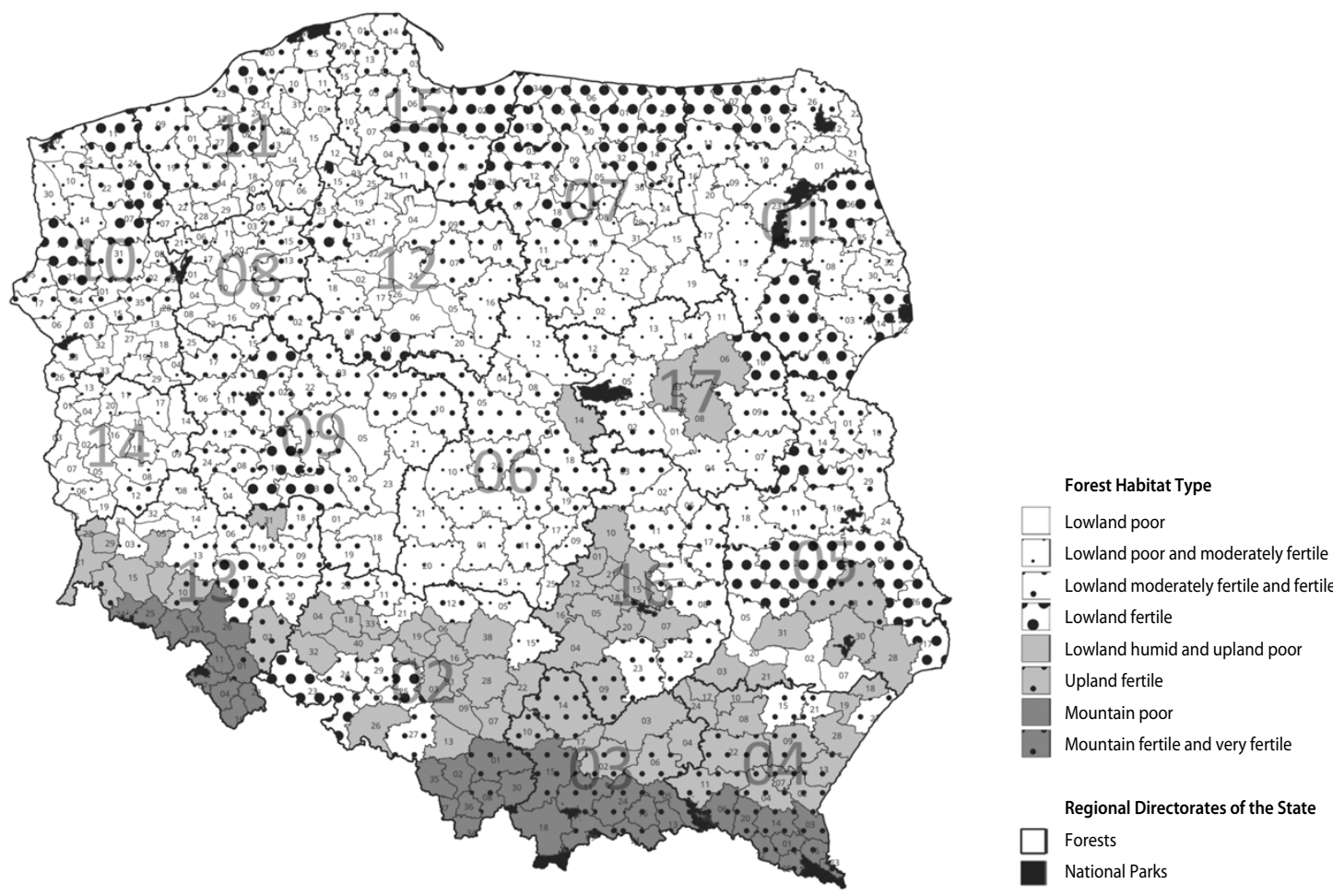

Figure 1. Groups of forest districts in terms of similar forest habitat types in 2017 and the land diversity index $\left(\mathrm{W}_{\text {tri }}\right)$ 
ately fertile 1 (3 forest districts) and lowland humid (1 forest district). The second largest habitat and slope group of forest districts was group 1 comprising 89 forest districts, where the $\mathrm{W}_{\text {tri }}$ index ranged from 1.0667 to 1.1345 . Forest districts in this group were classified into three forest district groups based on the structure of forest habitat types, that is, poor lowland 1 and poor lowland 2 (36 forest districts each) and lowland moderately fertile 2 ( 17 forest districts) habitats. The third habitat and slope group was group 3, comprising 70 forest districts with lowland poor 1 (44 forest districts) and lowland poor 2 (26 forest districts) habitats, where the land diversity index $\left(\mathrm{W}_{\text {tri }}\right)$ ranged from 1.0541 to 1.1158. On the other hand, the least numerous habitat and slope group of forest districts comprised 16 forest districts included in group 5, characterised by upland fertile (14 forest districts) and upland poor ( 2 forest districts) habitats. The land diversity index $\left(\mathrm{W}_{\text {tri }}\right)$ for this group of forest districts ranged from 1.1321 to 1.3504 . With a size similar to that of group 5, the eighth habitat and slope group of forest districts comprises 17 forest districts and the sixth habitat and slope group comprises 20 forest districts. A distinguishing feature of these two groups of habitat and slope forest districts is their formation from mountain habitats. And so, the group of eight was composed of 16 forest districts with poor mountain habitats and 1 forest district with fertile mountain habitats (with some upland habitats), while the sixth group of habitat and slope forest districts was composed of 12 forest districts with very fertile mountain habitats and 8 forest districts with fertile mountain habitats (with some upland habitats). The land diversity indices $\left(\mathrm{W}_{\mathrm{tri}}\right)$ for groups 8 and 6 of habitat and slope forest districts were in the range 1.312-1.592 and $1.3167-1.5924$, respectively.

The distinguishing features of each created habitat and slope group were reflected in the amount of standard unit costs of wood extraction determined on the basis of data from the year 2017. Among the eight forest district groups, the highest standard unit costs of wood extraction in the amount of $50.43 \mathrm{PLN} / \mathrm{m}^{3}$ were estimated for a group of six forest districts. These were the forest districts with fertile and very fertile mountain habitats, where the share of fresh mountain forest (LGśw) was almost $80 \%$, and they were distinguished by the highest average land diversity index among all forest district groups (1.4369). Forest districts in the second position (fifth habitat and slope group of forest districts), with a standard unit cost of wood extraction amounting to $39.40 \mathrm{PLN} / \mathrm{m}^{3}$, were the units characterised by upland habitats (with over $70 \%$ share of fresh upland forest - Lwyz) and an average land diversity index of 1.2492. The eighth habitat and slope group of forest districts was ranked third, with the standard unit costs of wood extraction at the level of $38.25 \mathrm{PLN} / \mathrm{m}^{3}$. This group included all forest districts with poor mountain habitats (16 forest districts) and 1 forest district from the group of mountain fertile habitats and with an average land diversity index of 1.4252 . In turn, the lowest standard unit costs $\left(20.65 \mathrm{PLN} / \mathrm{m}^{3}\right)$ for this forest work were calculated for the third habitat and slope group of forest districts characterised by poor lowland habitats with almost $60 \%$ share of fresh coniferous forest habitat (Bśw) and the lowest average land diversity index of all forest district groups (1.0843).

Table 1 shows the weighted average standard unit costs of wood extraction, calculated according to the method of grouping forest districts with similar natural and forest conditions, as well as the real and planned costs (calculated according to the weighted average performance), and also a comparison of the standard cost deviations from the real and planned costs according to the RDSF.

The weighted average standard cost of wood extraction for the State Forests in 2017 was $25.75 \mathrm{PLN} / \mathrm{m}^{3}$. The highest weighted average standard costs of this forest work were calculated for the RDSFs in Kraków (42.11 PLN $/ \mathrm{m}^{3}$ ), Krosno (38.96 PLN $/ \mathrm{m}^{3}$ ) and Wrocław (30.92 PLN $/ \mathrm{m}^{3}$ ). Wood extraction in the forest divisions of these directorates is carried out in upland and mountain areas with a large variety of terrain. The lowest standard costs were calculated for the so-called 'coniferous forest' directorates, that is, the RDSFs in Zielona Góra $\left(21.68 \mathrm{PLN} / \mathrm{m}^{3}\right)$, Piła $\left(22.35 \mathrm{PLN} / \mathrm{m}^{3}\right)$ and Torun $\left(22.46 \mathrm{PLN} / \mathrm{m}^{3}\right)$, where wood extraction is most often carried out in flat areas and the dominant habitats are dry and poor.

Across the State Forests, the deviation of standard unit costs from real costs amounted to $-7.38 \%$ $\left(-2.05 \mathrm{PLN} / \mathrm{m}^{3}\right)$, including the overestimation of standard unit costs compared to the real unit costs that was recorded for 5 RDSFs and the underestimation that was recorded for 12 RDSFs. However, the deviation of standard unit costs from the planned costs across the 
Table 1. Weighted average (by volume) standard, real and planned unit costs of felling and producing wood assortment in 2017 and comparison of deviations between costs, according to the RDSFs

\begin{tabular}{|c|l|c|c|c|c|c|}
\hline \multirow{2}{*}{ No. } & \multirow{2}{*}{$\begin{array}{l}\text { Regional } \\
\text { State Forests }\end{array}$} & \multicolumn{2}{|c|}{ Average costs weighted by volume $\left(\mathrm{PLN} / \mathrm{m}^{3}\right)$} & \multicolumn{2}{c|}{ Deviations of standard unit costs (\%) from } \\
\cline { 3 - 7 } & planned & real & standard & real costs & planned costs \\
\hline 1 & Białystok & 22.56 & 23.21 & 23.70 & 2.11 & 5.05 \\
\hline 2 & Katowice & 30.22 & 35.07 & 29.72 & -15.24 & -1.64 \\
\hline 3 & Kraków & 47.12 & 47.07 & 42.11 & -10.53 & -10.63 \\
\hline 4 & Krosno & 42.78 & 48.21 & 38.96 & -19.19 & -8.94 \\
\hline 5 & Lublin & 26.75 & 27.24 & 24.85 & -8.78 & -7.11 \\
\hline 6 & Lódź & 20.93 & 22.53 & 23.35 & 3.62 & 11.54 \\
\hline 7 & Olsztyn & 23.81 & 24.82 & 24.41 & -1.65 & 2.52 \\
\hline 8 & Piła & 19.35 & 20.52 & 22.35 & 8.90 & 15.49 \\
\hline 9 & Poznań & 20.67 & 28.54 & 22.67 & -20.57 & 9.68 \\
\hline 10 & Szczecin & 22.17 & 23.26 & 23.62 & 1.55 & 6.55 \\
\hline 11 & Szczecinek & 24.80 & 24.84 & 23.27 & -6.34 & -6.19 \\
\hline 12 & Toruń & 21.52 & 27.73 & 22.46 & -18.99 & 4.39 \\
\hline 13 & Wrocław & 28.32 & 28.88 & 30.92 & 7.08 & 9.19 \\
\hline 14 & Zielona Góra & 20.49 & 21.89 & 21.68 & -0.95 & 5.81 \\
\hline 15 & Gdańsk & 25.19 & 30.19 & 23.70 & -21.49 & -5.90 \\
\hline 16 & Radom & 26.95 & 28.95 & 26.14 & -9.71 & -3.01 \\
\hline 17 & Warszawa & 24.12 & 32.72 & 23.88 & -27.02 & -1.00 \\
\hline & Lasy Państwowe & 25.63 & 27.80 & 25.75 & -7.38 & 0.46 \\
\hline
\end{tabular}

State Forests was only $0.46 \%\left(0.12 \mathrm{PLN} / \mathrm{m}^{3}\right)$, including the overestimation of standard unit costs compared to the planned unit costs that was recorded for nine RDSFs and underestimation recorded for eight RDSFs.

In order to investigate the relationship between the real and planned unit costs and the standard unit costs of wood extraction, developed on the basis of the method of grouping forest districts with similar natural and forest conditions, the Pearson linear correlation test (Pearson's $r$ coefficient) was applied. A considerable correlation $(r=0.75)$ at the significance level of $p<0.001$ was found between the real unit costs and the planned unit costs of wood extraction in forest districts, and a very heavy correlation $(r=0.86)$ at the significance level of $p<0.001$ was found between the real and planned unit costs and the standard unit costs of wood extraction calculated for forest districts. On the other hand, a high correlation $(r=0.65)$ at the significance level of $p<0.001$ was found between the real unit costs of wood extraction and the standard unit costs of wood extraction calculated for forest districts.

Furthermore, practically full correlation $(r=0.93)$ at the significance level of $p<0.001$ was found between the weighted average real unit costs and the weighted average planned unit costs of wood extraction for the RDSFs. Another virtually full correlation $(r$ coefficient $=0.91$ and 0.98$)$ at the significance level of $p<0.001$ was found between the weighted average real unit costs and the weighted average planned unit costs, and the weighted average standard unit costs of wood extraction calculated for the RDSF. The test used to measure the significance of the Pearson's $r$ correlation coefficient showed the absence of significant statistical differences between the average real, planned and standard unit costs of wood extraction, calculated based on the clustering method of forest districts with similar natural and forest conditions and $\operatorname{RDSF}$ ( $p=0.068$ and 0.43 , respectively). 


\section{Discussion}

In an age of forest management progressive greening, a decreasing trend in profitability of the basic activity of forest districts (excluding income from the sale of wood) is related to the growing tendency towards increasing costs of forest districts' basic activity. It means that the State Forests should not only search for additional revenues unrelated to the sale of wood, but also, above all, take measures to rationalise the costs in all activity areas (Lotz 2019). Departing from even-aged and single-species stands towards less-intensive forestry, more focused on carbon storage, will also increase the costs of harvesting (Vaukonen and Packalen 2019). Therefore, it is essential to carry out studies on forestry works, which are useful in the State Forests' business practice and are intended to identify the influence of various environmental factors on the economic aspect of forest management (Gostołek et al. 2018).

The method of grouping forest areas based on their natural and production conditions, using cluster analysis, was reported in the study by Shegelman et al. (2019). In the authors' opinion, it enables effective forest management and simplifies a decision-making process related to the selection of harvesting technology and machinery. The analysis of the factors shaping the value of real unit costs of wood extraction, carried out in this study, showed the relationships between the average real costs of wood extraction, and the structure of forest habitat types and the value of the land diversity index $\left(\mathrm{W}_{\text {tri }}\right)$, calculated for all forest districts in the country. This became the basis for the creation of eight habitat and slope groups of forest districts. The influence of a specific forest habitat type results, inter alia, from the fact that it is characterised by specific fertility and humidity. Along with the increasing fertility of forest habitat types, difficulties increase in wood extraction, which are related to soil surface sodding, the need to protect seedlings, underwood and undergrowth. On the other hand, with the increase of humidity in forest habitats, wood extraction becomes a problem in wetlands, muddy and marshy areas, as well as in areas after furrowing and bedding. The other factor shaping the costs, that is, the land diversity index $\left(\mathrm{W}_{\text {tri }}\right)$, results from wood extraction and the resulting difficulties depending on the degree of terrain diversity, for example, in flat and hilly areas with a gentle relief, on a sloping or slanting hillside or on a very steep and precipitous slope.

The work efficiency in the harvesting process, which is closely related to the amount of costs incurred, was pointed out by Stampfer (1999), who emphasised that terrain conditions, mainly the slope and topography, as well as the soil-bearing capacity are the main factors determining work efficiency, and thus the costs of harvesting works. The level of training, experience of forestry machinery operators and the size of harvested trees (Mederski 2013; Lopes and Pagnussat 2017; Viser and Spinelli 2012; Wenhold et al. 2019), as well as the category and size of the cutting area (Proto et al. 2018) are also of high importance.

Statistically insignificant differences were recorded in the scale of the State Forests between standard, and real and planned unit costs of wood extraction. On the contrary, significant variations were noted between the weighted average standard unit costs and the weighted average real and planned costs calculated for individual RDSFs. And so, the highest underestimation of the standard unit costs of wood extraction in relation to the real costs incurred in 2017 was recorded in the RDSFs in Warsaw (227.02\%), Gdańsk (-21.49\%), Poznań (-20.57\%), Krosno (-19.19\%) and Torun (-18.99\%). Underestimation of standard costs in the forest districts of RDSF in Warsaw may be associated with the problem of unreliable and incomplete data that are necessary to calculate the real (incurred) unit costs of wood extraction. Out of 14 forest districts under RDSF in Warsaw, in 2017, 5 forest districts with unreliable or incomplete data were recorded. The reason for the differences that were found might have been the calculation of real unit costs of wood extraction on the basis of other forest districts and comparing them with standard costs calculated for groups of forest districts with similar wood extraction conditions as in the forest districts of Warsaw RDSF. A similar reason as in the case of the forest districts of Warsaw RDSF for underestimating the standard unit costs of wood extraction in relation to the real costs incurred in 2017 in the forest districts of Poznań and Krosno could have been the absence of information or unreliable information obtained on the size of tasks.

The problem of RDSFs in Warsaw, Poznań and Krosno leads to the conclusion that improving the methodology for determining standard unit costs would primarily involve explaining the causes of incompleteness 
or unreliability of data regarding the real unit costs of wood extraction. The probable reasons for the absence of information on the volume of wood extraction may include, among others:

- the usual practice in some forest districts related to setting, in tenders for forest management services, a single rate for harvesting, without any division into cutting, assortment production and wood extraction;

- wood chipping with self-propelled wood chippers, without the need to extract wood and

- issuing tenders by forest districts for so-called 'harvester' packages, which in harvesting technology with the use of multi-operational machines allows cutting and assortment production to be carried out together with wood extraction.

The underestimation of the standard unit costs of wood extraction in relation to the real costs incurred in 2017, recorded in the RDSFs in Gdańsk and Toruń, resulted mainly from the increased costs (increased wood extraction difficulty zones) related to the removal of the effects of wind damage (stem breakage and uprooting) that had taken place in August 2017. In the natural disaster conditions, a different regularity was demonstrated by the analysis of costs of basic activity in the Węgierska Górka Forest District, which was conducted by Sikora and Ukalska (2014). The authors stated that if the unit costs of cutting and assortment production in the Węgierska Górka Forest District increased significantly after the hurricane in 2004, as well as in connection with the removal of trees inhabited after the insect outbreak in the years 2007-2008, the unit costs of wood extraction were at a similar level and showed a similar upward trend as the unit costs for groups of comparative forest districts, that is, Krościenko, Limanowa, Łosie, Myślenice, Nawojowa, Nowy Targ, Piwniczna and Stary Sącz. The increase in the cost of wood extraction in the forest districts of Gdańsk and Torun RDSFs may be associated with a greater degree of damage and increased difficulties in wood extraction than in the Węgierska Górka forest district.

Further, intense competition in the forest services market resulted in overestimation of the standard unit costs of wood extraction in relation to real costs in the forest districts of the RDSFs in Piła (8.90\%), Wrocław (7.08\%) and Łódź (3.62\%). In addition, the reason for overestimating the standard unit costs in relation to the planned costs is planning the costs of wood extraction by forest districts with great caution. The aforementioned forest divisions of RDSFs in Piła (15.49\%) and Łódź (11.54\%) may constitute a good example.

The coefficient of variation showed the strongest differentiation of the real unit costs of wood extraction for forest districts. It reached the value of 41.07, which allowed to define this group of statistical data as an average variability group (Sobczyk 2007). The coefficient of variation of standard unit costs of wood extraction for forest districts achieved a value of 26.46, which accounted for $64.43 \%$ of the value of the coefficient calculated for the real unit costs of wood extraction for forest districts. It is the result of the applied method of grouping forest districts with similar natural and forest conditions, in which, first of all, so-called outliers are eliminated (values beyond plus and minus 2 standard deviations from the arithmetic mean), and secondly, the forest districts included in a given habitat and slope group have the same unit costs. The results of comparing the coefficient of variation for the planned unit costs of wood extraction with the coefficient of variation for the real unit costs of wood extraction may be, to a large extent, a measure of forest districts' planning accuracy for this financial category. The coefficient of variation of the unit costs of wood extraction planned by forest districts for 2017 was 34.72, which accounted for $84.54 \%$ of the coefficient of variation of the real (incurred) unit costs of wood extraction in the forest districts in the analysed year. Thus, the difference between the coefficients amounting to $15.46 \%$ may be the result of economic events that took place in 2017, including a natural disaster in August of the mentioned year. On the contrary, when analysing the coefficients of variation weighted by the volume of standard tasks, real and planned unit costs of wood extraction at the RDSFs, it may be noticed that they were characterised by low and average variability. The lowest variability coefficient was recorded for the weighted average standard unit costs of wood extraction (22.43), and the highest one for the weighted average planned unit costs of wood extraction calculated for the RDSFs (29.04). It was 27.35 for the weighted average real unit costs of wood extraction at the RDSFs.

The presented method is based on specifying standard unit costs of wood extraction on the basis of natural units $\left(\mathrm{m}^{3}\right)$, which results from the role that standard costs should play in the State Forests' financial system. The need to base cost standardisation of this group of 
forestry works on natural units has been confirmed in the information collected from 402 forest districts in the first quarter of 2018 for the purpose of the Joint Commission of the State Forests and organisations associating forest entrepreneurs (Komisja 2018). The analysis of wood extraction works accounting system clearly shows that $81.8 \%$ of the analysed forest districts ( 329 forest districts) accounted for works in natural units $\left(\mathrm{m}^{3}\right), 14.2 \%$ (57 forest districts) according to labour consumption catalogues and 16 forest districts (4,0\%) applied a mixed system. In the forestry entrepreneurs' opinion, a more advantageous solution for forestry companies is the use of labour consumption catalogues when accounting for wood extraction works. This takes place particularly with changing the position of cuts and changing the difficulty zones in the wood extraction process, which, with labour consumption catalogue, enables the labour consumption to be corrected. If a single rate for $1 \mathrm{~m}^{3}$ of wood extraction is applied, it is often impossible for the entire forest district. However, in the case of using one rate for skidding $1 \mathrm{~m}^{3}$ of wood, it is often not possible for the entire forest district.

The tables of labour consumption in wood extraction allow for calculation of the time necessary to perform wood extraction depending on the distance; however, according to Paszkiewicz (2009), a weak point of wood extraction distance calculation (based on the data recorded in transport bills) is to rely solely on the 'LAS' system databases, especially when the entity does not record data reliably. In such a case, an error in one or a few forest districts will result in errors in the calculation of the cost vs. income ratio in all other forest districts of a given RDSF.

Further work on the standardisation of the unit cost of skidding should take into account the issues related to making the forest available via roads, strip roads (sometimes their construction is necessary, especially in mountain areas) and permanent timber yards (Kamiński et al. 2020).

\section{Conclusions}

The standardisation of unit costs of forestry works should serve for the purpose of determining the costs that are deemed correct and reasonable, as well as needed for the performance of a specific business task in the given natural, forest and economic conditions of forest districts. The method of standardising unit costs of wood extraction presented in this study was used to prepare provisional financial and business plans at the State Forests for the years 2014-2016 and 2018. When applying the standards, an important problem arises with their verification, on account of changes taking place in the operating conditions of forest districts. The necessity of annual updates of standard unit costs of wood extraction for forest districts is dictated by the annual change in the volume of economic tasks of forest districts and the structure of forest habitat types at forest districts, resulting mainly from the changes in forest management plans for approximately $10 \%$ of the forest districts (around 40 units), as well as frequent changes in the size of forest districts' forest area. This change forces the Forest Management and Geodesy Bureau to verify the land diversity indicators $\left(W_{t r i}\right)$ used in the presented method of standardising this forest work.

The following conclusions may be drawn based on the foregoing considerations:

- The method of grouping forest districts with similar natural and forest conditions should be applied to standardise unit costs of wood extraction, and the results of such standardisation should be used in the State Forests' financial system.

- Deviations from the standard unit costs of wood extraction with respect to the real unit costs should be analysed in further studies. The overriding criterion for the classification of these deviations should be their significance, evaluated under the assumption of a specific, acceptable tolerance level.

- Additional analyses are also required for the socalled outliers, which have been disregarded in the presented method of grouping forest districts with similar natural and forest conditions. It is necessary to investigate the factors (founded or unfounded) that cause these deviations at the forest districts which achieve real costs differing from the costs of other forest districts included in the same habitat and slope group.

- Improvement of the method of standardising unit costs of wood extraction should include appropriate recording of data on the volume and incurred costs of wood extraction, which would ensure the credibility and completeness of the data. 


\section{ACKNOWLedgements}

This paper is based on the results of the projects, 'Standard unit costs in the financial system of the State Forests' (BLP-411) and 'Development of standard unit costs of selected works from the basic activity of forest districts' (BLP-376), commissioned by the Directorate General of State Forests.

\section{References}

Gabrusewicz, W. 2019. Metody analizy finansowej przedsiębiorstwa. Polskie Wydawnictwo Ekonomiczne, Warszawa.

Gabrusewicz, W., Czubakowska, K., Nowak, E. 2014. Rachunkowość zarządcza. Metody i zastosowania. Polskie Wydawnictwo Ekonomiczne, Warszawa.

Gostołek, R., Rutkowska, A., Adamowicz, K. 2018. Wpływ typu siedliskowego lasu na przychody uzyskiwane w ramach wczesnych i późnych trzebieży pozytywnych. Sylwan, 162 (3), 179-188. DOI: 10.26202/sylwan.2017065

Jerzemowska, M. 2018. Analiza ekonomiczna w przedsiębiorstwie. Polskie Wydawnictwo Ekonomiczne, Warszawa.

Kamiński, K., Szewczyk, G., Kocel, J. 2020. Standardization of complementary work time in timber harvesting processes. Folia Forestalia Polonica, Series A-Forestry, 62 (4), 258-269. DOI: 10.2478/ ffp-2020-0025

Kocel, J. 2018. Przygotowanie opracowania na potrzeby prac nad prowizorium planu finansowo-gospodarczego Lasów Państwowych na rok 2019. Dokumentacja IBL, Sękocin Stary.

Kocel, J., Grabowski, G. 2002. Badanie funkcjonowania modelowych kosztów jednostkowych wybranych prac z zakresu działalności podstawowej nadleśnictw. Dokumentacja IBL, Warszawa.

Kocel, J., Królicki, A., Mionskowski, M., Grabowski, G. 2013. Opracowanie standardowych kosztów jednostkowych wybranych prac z zakresu działalności podstawowej nadleśnictw. Dokumentacja IBL, Sękocin Stary.

Kocel, J., Kwiecień, R., Grabowski, G., Jeziorański, S. 1999. Badanie prawidłowości kształtowania się jednostkowych kosztów wybranych działów gospodarki leśnej. Dokumentacja IBL, Warszawa.

Kocel, J., Wysocka-Fijorek, E. 2020. Określanie standardowych kosztów jednostkowych wybranych $\operatorname{prac}$ z zakresu hodowli lasu. Sylwan, 164 (3), 196-205. DOI: 10.26202/sylwan.2019098

Kocel, J., Wysocka-Fijorek, E., Lotz, D., Mionskowski, M., Grabowski, G. 2017. Standardowe koszty jednostkowe w systemie finansowym Lasów Państwowych. Dokumentacja IBL, Sękocin Stary.

Kocel, J., Wysocka-Fijorek, E., Mionskowski, M. 2019. Metody standaryzacji kosztów jednostkowych wybranych prac z zakresu hodowli lasu. Sylwan, 163 (11), 892-902. DOI: 10.26202/sylwan.2019065

Komisja Wspólna Lasów Państwowych i organizacji zrzeszających przedsiębiorców leśnych 2018. Materiały ze spotkania w dniu 25.04.2018 r. DGLP, Warszawa.

Laurow, Z. 1999. Pozyskanie drewna. Wydawnictwo SGGW, Warszawa.

Lopes, E.S., Pagnussat, M.B. 2017. Effect of the behavioral profile on operator performance in timber harvesting. International Journal of Forest Engineering, 28 (3), 134-139. DOI: 10.1080/14942119.2017.1328847

Losch, D., Wantia, N., Rossman, J. 2015. A novel cost estimation approach for wood harvesting operations using symbolic planning. Procedia Computer Science, 51, 306-315. DOI: 10.1016/j.procs.2015.05.247

Lotz, D. 2019. Wpływ dochodów pochodzących z innych źródeł niż sprzedaż drewna na sytuację finansową Państwowego Gospodarstwa Leśnego Lasy Państwowe. Praca doktorska wykonana w Zakładzie Zarządzania Zasobami Leśnymi Instytutu Badawczego Leśnictwa w Sękocinie Starym, Sękocin Stary.

Mederski, P.S. 2013. The potential of harwester use for thinning operations in mixed birch-pine stands (in Polish with English summary). Wydawnictwo Uniwersytetu Przyrodniczego w Poznaniu, Rozprawy naukowe, zeszyt 460, Poznań.

Nowak, E. 2018. Analiza kosztów w ocenie działalności przedsiębiorstwa. CeDeWu Sp. z o.o., Warszawa.

Nowak, E. 2018a. Rachunek kosztów w jednostkach prowadzących działalność gospodarczą. EKSPERT, Warszawa. 
Nowak, E. 2019. Analiza i kontrola kosztów przedsiębiorstwa. CeDeWu Sp. z o.o., Warszawa.

Paszkiewicz, A. 2009. Metoda ustalania relacji kosztów do przychodów w procesie budżetowania w Państwowym Gospodarstwie Leśnym Lasy Państwowe. Praca doktorska wykonana w Instytucie Badawczym Leśnictwa w Sękocinie Starym, Sękocin Stary.

Proto, A.R. et al. 2018. Factors affecting forwarder productivity. European Journal of Forest Research, 137, 143-151. DOI: 10.1007/s10342-017-1088-6

Riley, S.J., DeGloria, S.D., Elliot, R. 1999. A terrain ruggedness index that quantifies topographic heterogeneity. Intermountain Journal of Sciences, 5 (1/4), 23-27.

Sadowski, J., Moskalik, T., Zastocki, D. 2014. The effectiveness of the timber harvesting by PONSSE Ergo harvester in selected forest stands (in Polish with Englisz summary). Studia i Materiaty Centrum Edukacji Przyrodniczo-Leśnej, 16 (2b[39]), 126-132.

Shegelman, I. et al. 2019. Analysis of natural-production conditions for timber harvesting in European North of Russia. Central European Forestry Journal, 65, 81-91. DOI: 10.2478/forj-2019-0006

Sikora, A.T., Ukalska, J. 2014. Koszty działalności podstawowej w warunkach klęsk żywiołowych w Nadleśnictwie Węgierska Górka. Leśne Prace Badawcze, 75 (3), 263-275. DOI: 10.2478/frp-2014-0026

Sobczyk, M. 2007. Statystyka. Wydawnictwo Naukowe PWN, Warszawa.

Sojak, S. 2017. Podstawy rachunku kosztów, rachunkowości zarządczej i zarządzania finansami. Stowarzyszenie Księgowych w Polsce - Zarząd Główny w Warszawie Instytut Certyfikacji Zawodowych Księgowych, Warszawa.

Stampfer, K. 1999. Influence of terrain conditions and thinning regimes on productivity of a track-based steep slope harvester. In: Proceedings of the International Mountain Logging and $10^{\text {th }}$ Pacific Northwest Skyline Symposium (eds. J. Sessions, W. Chung). Corvallis, Oregon, 78-87.
Szewczyk, G., Sowa, J., Kulak, D., Stańczykiewicz, A. 2013. Czynniki kształtujące koszty usług leśnych przy pozyskaniu drewna. Konferencja ,Sektor usług leśnych - dzisiaj i jutro", Puszczykowo, 19-20 lutego 2013.

Vauhkonen, J., Packalen, T. 2019 Shifting from evenaged management to less intensive forestry in varying proportions of forest land in Finland: impacts on carbon storage, harvest removals, and harvesting costs. European Journal of Forest Research, 138, 219-238. DOI: 10.1007/s10342-019-01163-9

Visser, R., Spinelli, R. 2012. Determining the shape of the productivity function for mechanized felling and felling-processing. Journal of Forest Research, 17, 397-402. DOI: 10.1007/s10310-011-0313-2

Walesiak, M., Gatnar, E. 2009. Statystyczna analiza danych z wykorzystaniem programu R. Wydawnictwo Naukowe PWN, Warszawa.

Wenhold, R., Ackerman, P., Ackerman, S., Gagliardi, K. 2020. Skills development of mechanized softwood sawtimber cut-to-length harvester operators on the Highveld of South Africa. International Journal of Forest Engineering, 31 (1), 9-18. DOI: 10.1080/14942119.2019.1578561

Zając, S., Kaliszewski, A. 2014. Ekonomiczne aspekty ekologizacji zagospodarowania lasu. In: Przyrodnicze, społeczne i gospodarcze uwarunkowania oraz cele i metody hodowli lasu. Zimowa Szkoła Leśna. IBL, Sękocin Stary, 18-20 marca 2014, 195-209.

Zarządzenie. 1998. Zarządzenie nr 53 Dyrektora Generalnego Lasów Państwowych z dnia 27 października 1998 r. w sprawie sposobu ustalania i ewidencjonowania wartości niewykonanych zadań rzeczowych z zakresu działalności podstawowej nadleśnictw i przeprowadzenia oceny wyniku nadleśnictwa $\mathrm{w}$ działalności podstawowej i administracyjnej finansowanej ze środków własnych (E-0892-10p33/98). DGLP, Warszawa.

Zeliaś, A. 2010. Metody statystyczne. Polskie Wydawnictwo Ekonomiczne, Warszawa. 